\title{
Nitrogen sediment fluxes in an upwelling system off central Chile (Concepción Bay and adjacent shelf) during the 1997-1998 El Niño
}

\author{
Flujos de compuestos nitrogenados desde los sedimentos, en un sistema de surgencia de \\ Chile central (Bahía Concepción y plataforma adyacente) durante El Niño 1997-1998
}

PRAXEDES MUÑOZ ${ }^{1,2}$, MARCO A. SALAMANCA ${ }^{3}$, CARLOS NEIRA $^{4} \&$ JAVIER SELLANES $^{2}$

\author{
${ }^{1}$ Departamento de Biología Marina, Universidad Católica del Norte, Larrondo 1281, \\ Coquimbo, Chile; e-mail: praxedes@ucn.cl \\ ${ }^{2}$ Centro de Investigación Oceanográfica en el Pacífico Sur-oriental (FONDAP-COPAS), \\ Casilla 160-C, Cabina 3, Concepción, Chile \\ ${ }^{3}$ Departamento de Oceanografía, Universidad de Concepción, Casilla 160-C, Concepción, Chile \\ ${ }^{4}$ Integrative Oceanography Division, Scripps Institution of Oceanography, La Jolla, California 92093-0218, USA
}

\begin{abstract}
Two stations representing coastal and shelf environments (bay of Concepción and adjacent shelf, respectively) were sampled in order to assess benthic nitrogen fluxes. During the study period anomalously high oxygen bottom waters conditions were observed, coinciding with the 1997-1998 El Niño event. From both sites, intact sediment cores were collected for incubation experiments to directly estimate total ammonium fluxes. Porewater chemistry was also assessed to estimate diffusive fluxes of nitrogen compounds $\left(\mathrm{NH}_{4}^{+}, \mathrm{NO}_{3}^{-}\right.$and $\left.\mathrm{NO}_{2}^{-}\right)$. The $\mathrm{NH}_{4}{ }^{+}$flux from incubation experiments ranged from 0.55 to $2.18 \mathrm{mmol} \mathrm{m}^{-2}$ day ${ }^{-1}$ in the inner bay and from 1.84 to $2.14 \mathrm{mmol} \mathrm{m}^{-2}$ day ${ }^{-1}$ on the shelf. $\mathrm{NO}_{3}^{-}$diffusive fluxes to the sediments were observed in the bay in March $\left(-17 \times 10^{-2} \mathrm{mmol} \mathrm{m}^{-2}\right.$ day $\left.^{-1}\right)$ and on the shelf in November $\left(-2.7 \times 10^{-2} \mathrm{mmol} \mathrm{m}^{-2} \mathrm{day}^{-1}\right)$, associated with the lowest $\mathrm{NH}_{4}^{+}$diffusive fluxes and coincident with a stronger gradient of $\mathrm{Eh}$ in the first centimeters of the sediments. Besides, total $\mathrm{NH}_{4}{ }^{+}$fluxes lower than in normal periods were observed, suggesting the influence of less reducing conditions, consequence in turn of the lower fluxes of particulated organic material and higher dissolved oxygen in the bottom waters. These conditions were probably imposed by the El Niño event. On the other hand, and relative to previous reports, an increase of irrigation coefficients (DI) was estimated. Thus, the flux extension of other nitrogen compounds could have acquired relevance in relation to $\mathrm{NH}_{4}^{+}$fluxes during the study period.
\end{abstract}

Key words: ammonia, pore-water nutrients, sediment-water exchanges, coastal upwelling, El Niño event.

\section{RESUMEN}

Se analizaron los flujos de compuestos nitrogenados desde los sedimentos en dos áreas representativas de condiciones costeras y de plataforma (Bahía Concepción y plataforma adyacente, respectivamente). Durante el período de muestreo las aguas de fondo presentaron un anómalamente alto contenido de oxígeno disuelto, coincidente con el evento El Niño 1997-1998. De ambos sitios, se incubaron testigos de sedimento intactos para determinar los flujos totales de $\mathrm{NH}_{4}{ }^{+}$. Además se determinó la concentración de $\mathrm{NH}_{4}{ }^{+}, \mathrm{NO}_{3}{ }^{-}$y $\mathrm{NO}_{2}{ }^{-}$en el agua intersticial para estimar los flujos difusivos de compuestos nitrogenados en la interfase agua-sedimento. Los flujos de $\mathrm{NH}_{4}^{+}$totales variaron entre 0,55 y $2,18 \mathrm{mmol} \mathrm{m}^{-2}$ día ${ }^{-1}$ al interior de la bahía y entre 1,84 a 2,14 mmol m${ }^{-2}$ día ${ }^{-1}$ en la plataforma. Se observaron flujos difusivos de $\mathrm{NO}_{3}{ }^{-}$en dirección a los sedimentos al interior de la bahía en Marzo de $1998\left(-17 \times 10^{-2} \mathrm{mmol} \mathrm{m}^{-2}\right.$ día $\left.^{-1}\right)$ y en la plataforma en Noviembre de 1997 ($2,7 \times 10^{-2} \mathrm{mmol} \mathrm{m}^{-2}$ día $^{-1}$ ) asociados a los flujos difusivos de $\mathrm{NH}_{4}^{+}$más bajos, coincidiendo esto con la mayor gradiente de Eh en los sedimentos superficiales. Además, los bajos flujos de $\mathrm{NH}_{4}{ }^{+}$medidos en comparación con mediciones previas, sugieren la influencia de un ambiente menos reductor, generado a su vez por la disminución del flujo de material orgánico particulado y por el aumento de las concentraciones de oxígeno disuelto en las aguas del fondo. Estas condiciones fueron generadas probablemente por el evento El Niño. También, con relación a reportes previos se registró un incremento en los coeficientes de irrigación (DI). Todo esto sugiere que durante este período los flujos de otros compuestos nitrogenados podrían haber adquirido relevancia con relación a los flujos de $\mathrm{NH}_{4}{ }^{+}$.

Palabras clave: amonio, nutrientes, agua intersticial, intercambio agua-sedimento, surgencia, evento El Niño. 


\section{INTRODUCTION}

The southeastern Pacific is one of the most productive systems in the world oceans. The continental shelf off central Chile at $\sim 36^{\circ} \mathrm{S}$ extends about $40 \mathrm{~km}$ offshore and is one of the widest and most productive shelf areas along the Chilean coast (Scholl et al. 1970, Bernal et al. 1989, Dellarosa 1998). The hydrography of the area is dominated by seasonal and episodic coastal upwelling in response to wind patterns associated with the Pacific anticyclonic gyre (Ahumada et al. 1983). The combined effect of these winds and the Coriolis force gives rise to the upwelling of ESSW (Equatorial Subsurface Water) characterized by high salinity, low oxygen and high nutrient content (Ahumada \& Chuecas 1979). The upwelled waters promote the phytoplanktonic growth and hence primary productivity. A maximum Chl-a concentration of about $50 \mathrm{mg} \mathrm{m}^{-2}$ (Ahumada et al. 1983, 1984, Ahumada 1989) and primary production values of 5.8 to $9.6 \mathrm{~g} \mathrm{C} \mathrm{m}^{-2}$ day $^{-1}$ (Fossing et al. 1995, Dellarosa 1998) have been measured in this area. A large fraction (ca. 25-40\%) of the primary production settles to the bottom (Bernal et al. 1989), where the major fraction of it is remineralized and its products, such as ammonium, released to the water column (Farías et al. 1996).

The warm phase of El Niño Southern Oscillation (ENSO) cycle in the tropical Pacific, i.e., El Niño, has been associated with climatic and economic impacts around the globe. El Niño has been described at several year intervals in the Peruvian-Chilean coasts (Enfield 1989, McPhaden 1999). This event is characterized by the presence of oxygen-rich and nutrient-poor waters that prevent high primary production during the upwelling periods. Off Concepción, during the 1997-1998 El Niño, warm waters and anomalous local winds (not favorable for upwelling) were observed, as well as high oxygen concentrations in the bottom waters (Gutiérrez 2000). Moreover, a substantially lower primary production, about $0.18-0.16 \mathrm{~g} \mathrm{C} \mathrm{m}^{-2}$ day $^{-1}$ (Ulloa personal communication) was measured. Other studies also indicate decreased quantity and quality of organic matter (Neira et al. 2001), compared to "normal" non-El Niño period. It is expected that these anomalous conditions could have promoted a different response of the biogeochemical process involved in the organic matter mineralization. These new conditions also affected the distribution and composition of macro - and meiofauna and, therefore, processes such as bioturbation (Gutiérrez et al. 2000, Neira et al. 2001), which is closely related to the magnitude of benthic fluxes. Thus, chemical and biological conditions during El Niño period could change the nutrient fluxes across the water-sediment interface.

The main objective of this study was thus to evaluate benthic nitrogen fluxes across the sediment-water interface in Concepción Bay (central Chile) during the 1997-1998 El Niño event. The results are also discussed in relation with existing data for the study area gathered during non-El Niño years.

\section{MATERIAL AND METHODS}

\section{Study site}

The hydrography of the study area is closely linked to the adjacent oceanic system with regard to the interannual, seasonal and short time fluctuations, and to the local wind regime. Predominant southwest winds develop an upwelling center between $35^{\circ}$ and $38^{\circ} \mathrm{S}$ (Brandhorst 1971, Ahumada \& Chuecas 1979, Arcos \& Salamanca 1984). On the seasonal time-scale, southwest winds usually blow for a week and are followed by a period of calm and northerly winds. Some authors have identified these periods as active and relaxed upwelling (Arcos \& Wilson 1984, Peterson et al. 1988, Sobarzo et al. 1997). This pattern causes strong temporal variability in the water column hydrography. The upwelled waters (ESSW, Equatorial Subsurface Water) located between 100-400 m (Brandhorst 1971), can be found over the continental shelf and sometimes even at the inner Concepción Bay during active upwelling, causing subtoxic conditions over the whole area (Ahumada et al. 1983, Roa et al. 1995).

The sediments are mainly constituted by soft and reduced muds, rich in organic matter (15-22 \%) (Carrasco 1986, Salamanca 1988). High $\mathrm{C}$ oxidation rates are reported at the sediment surface, mainly through sulfate reduction (Thamdrup \& Canfield 1996, Ferdelman et al. 1997), and ammonium fluxes to the overlying waters are about $10 \mathrm{mmol} \mathrm{m}^{-2}$ day $^{-1}$ (Farías et al. 1995, 1996). Nematodes represent more than $96 \%$ of the meiofauna (Neira et al. 2001), and macrofauna during nonEl Niño years is dominated $(85 \%)$ by the polychaete Parapronospio pinnata (Carrasco 1986). Giant filamentous bacteria of the genus Thioploca and Beggiatoa have been described for the shelf and bay sediments, where they occasionally occur in thick mats, reaching 
biomasses of up to $1 \mathrm{~kg} \mathrm{~m}^{-2}$ (Gallardo 1977 , Fossing et al. 1995, Schulz et al. 1996).

\section{Sampling}

Two study stations were selected, representing coastal (Station $4,36^{\circ} 38^{\prime}$ S, $73^{\circ} 02^{\prime} \mathrm{W} ; 27 \mathrm{~m}$ deep) and shelf (Station $18,36^{\circ} 30^{\prime} \mathrm{S}, 7^{\circ} 07^{\prime}$ $\mathrm{W} ; 88 \mathrm{~m}$ deep) environments. These were sampled in November 1997 and March 1998 (Fig. 1), where duplicate sediment cores $(70 \mathrm{~cm}$ length, $10 \mathrm{~cm}$ inner diameter) were collected with a mini-multicorer (MUC). Only selected, undisturbed cores with clear overlying water were used. The cores were kept refrigerated (ca. 3-4 ${ }^{\circ} \mathrm{C}$ ), protected from light and transported within six hours as a maximum to the Marine Biological Station of Universidad de Concepción. Water samples were taken at standard depths using Niskin bottles and dissolved oxygen (DO) was measured in three replicates by the modified Winkler method

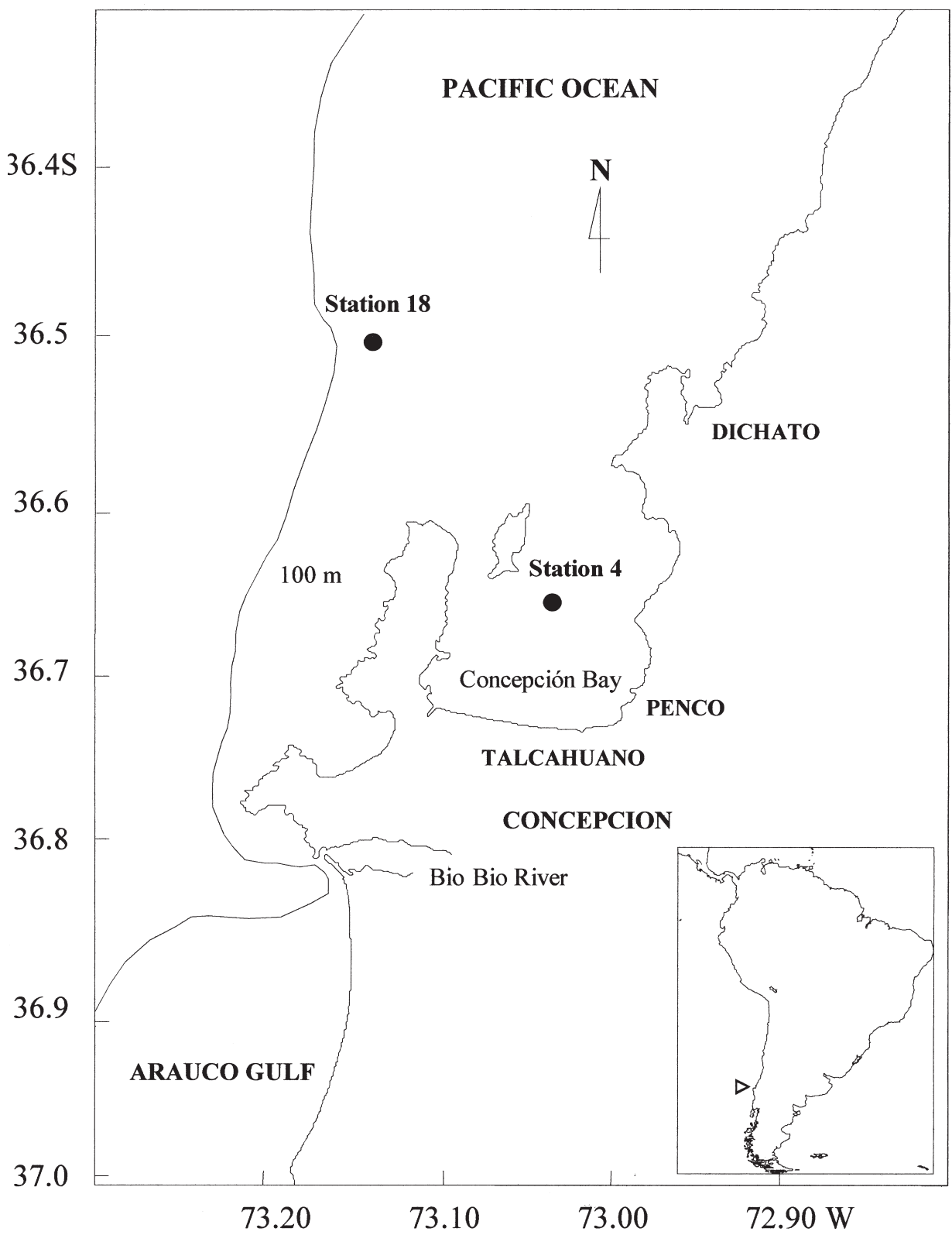

Fig. 1: Coring stations in Concepción Bay and adjacent shelf.

Estaciones de muestreo en Bahía Concepción y plataforma adyacente. 
(Williams \& Jerkinson 1982) using a DOSIMAT for titration and a photoelectric cell for end point detection.

\section{Pore water sampling and analysis}

Sediment profiles for redox potential (Eh) were measured at intervals of $1 \mathrm{~cm}$ down to $20 \mathrm{~cm}$ using a platinum standard combination electrode with a calomel internal reference (Mettler Toledo-InLab). Duplicated cores from the same sampling location were analyzed for $\mathrm{NH}_{4}{ }^{+}, \mathrm{NO}_{3}{ }^{-}$and $\mathrm{NO}_{2}^{-}$pore water concentration. Pore water samples were extracted by squeezing sediment sections of $1 \mathrm{~cm}$ under a $\mathrm{N}_{2}$ atmosphere through a $0.45 \mu \mathrm{m}$ mixed esters cellulose membranes (Gelman). The water thus obtained was immediately filtered again through GF/F filters (Whatman), stored in acid washed plastic vials and kept frozen $\left(-20{ }^{\circ} \mathrm{C}\right)$ until later analysis. Nitrogen compounds $\left(\mathrm{NO}_{3}{ }^{-}\right.$, $\mathrm{NO}_{2}{ }^{-}$and $\mathrm{NH}_{4}{ }^{+}$) were analyzed using a Bran and Luebbe TRAACS 800 autoanalyzer.

Porosity and water content were determined at $1 \mathrm{~cm}$ intervals by weight loss after drying $\left(70{ }^{\circ} \mathrm{C}\right)$ a known volume of sediment and assuming a sediment and water density of 2.65 $\mathrm{g} \mathrm{cm}^{-3}$ and $1.025 \mathrm{~g} \mathrm{~cm}^{-3}$, respectively (Buchanan 1984).

Pore water nutrient diffusion was estimated from pore-water concentration gradient between the top layer and 5 or $7 \mathrm{~cm}$ deep, according to Fick's first law (Berner 1980). A diffusion coefficient, corrected for temperature and tortuosity was used (Li 1974, Boudreau 1997).

\section{Benthic flux experiments}

Two $30 \mathrm{~cm}$ long, $8 \mathrm{~cm}$ inner diameter, undisturbed cores sub-sampled from original MUC cores were used for ammonium flux experiments across the water-sediment interface for each station. These cores contained approximately $15 \mathrm{~cm}$ of sediment covered by 15 $\mathrm{cm}$ of water (total volume $600 \mathrm{~mL}$ ). The overlying water was carefully replaced with bottom water before incubation. Cores were wrapped with aluminum foil to exclude light, and incubated for $6 \mathrm{~h}$ at the in situ bottom water temperature $\left(\sim 11{ }^{\circ} \mathrm{C}\right)$ after collection. Each core was capped and equipped with dissolved oxygen, temperature and $\mathrm{pH}$ sensors, and a magnetic stirrer for mixing during 6-8 h incubations. Initial ammonium samples were taken from the in situ bottom water and successive samples were obtained at different time intervals (every $10 \mathrm{~min}$ the first hour and from 10 to $20 \mathrm{~min}$ the next $5 \mathrm{~h}$ ). Concentrations were measured according to the modified Solorzano indophenol method (Grasshoff 1983). An analytical error of $3 \%$ was estimated using ammonium chloride standards.

Sediment-water fluxes in the incubated cores were estimated directly based on the best fit of the obtained time course curves, according with the best variance explained. A two way Analysis of Variance (ANOVA) was used to assess differences in ammonium total fluxes between sampling periods and stations. When significant differences were found, contrasts between groups were performed using the Tukey HSD a posteriori test (Zar 1974). The STATISTICA software was used for these purposes.

\section{RESULTS}

\section{Water column and sediment environmental settings}

The time course of the temperature and dissolved oxygen (DO) concentration in the area between May 1997 and March 2000 are shown in Fig. 2. A slight warming, mainly at the surface and anomalously high bottom water oxygen concentrations between November 1997 and May 1998 were evident. One year later, between November 1998 and March 1999, low oxygen concentrations $(<10 \mathrm{mM})$ and colder bottom water (around $11{ }^{\circ} \mathrm{C}$ ) conditions, considered typical for the area, returned. These anomalous conditions between May 1997 and May 1998 were attributed to the El Niño 19971998 event.

The redox potential (Eh) and the bottom water DO values during this study are shown in Table 1. For practical purposes and to avoid large tables, the sediment column was divided in two layers: surface $(0-3 \mathrm{~cm})$ and bottom $(>3$ $\mathrm{cm})$, coincident with the redox boundary (change between positive and negative values) in two cases. Sediment layers with Eh values lower than $-100 \mathrm{mV}$ are indicated at the footnote. Differences between stations and periods were observed. Negative values of Eh were found in the bay sediments during November, while bottom water depicted oxygen concentrations of $98.1 \mathrm{mM}$, which are unusually high for this period. During March, less reduced surface sediments $(0-3 \mathrm{~cm})$ were observed within the bay as well as lower bottom water DO concentrations $(16.9 \mathrm{mM})$. At the shelf site, sediments presented positive Eh surface values during both samplings. Bottom water DO concentrations varied from 25.4 to 16.4 mM, November 1997 to March 1998, respectively. 

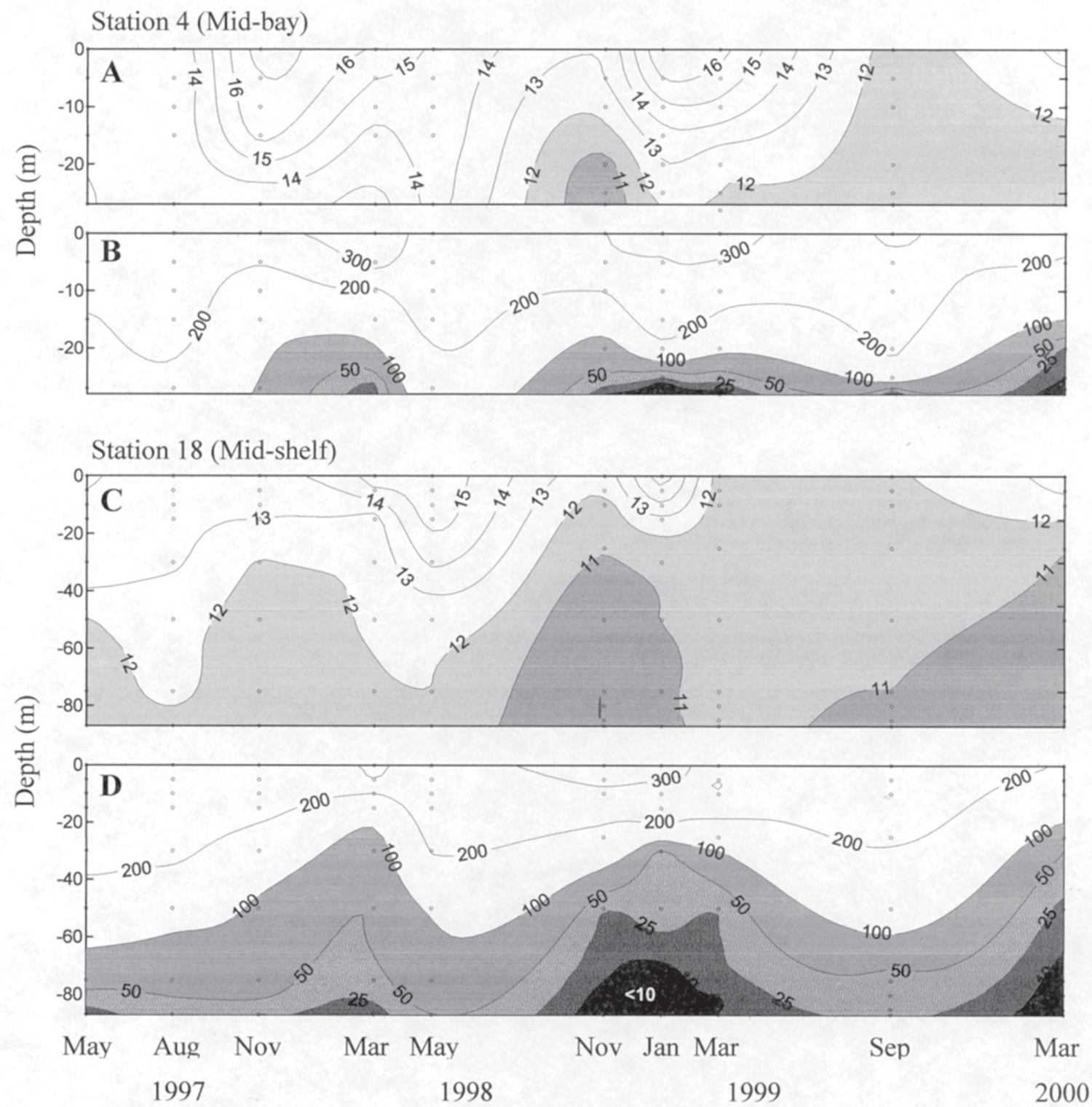

Fig. 2: Time course of temperature $\left({ }^{\circ} \mathrm{C}\right)$ and oxygen $(\mathrm{mM})$ representing El Niño (May 1997May1998) and post-El Niño conditions (May 1998-March 2000) at the mid-bay of Concepción and mid-shelf sites. Each two contour graph set, represents temperature and oxygen concentration for stations 4 ( $\mathrm{A}$ and $\mathrm{B})$ and $18(\mathrm{C}$ and $\mathrm{D})$, respectively.

Evolución temporal de la temperatura $\left({ }^{\circ} \mathrm{C}\right)$ y oxígeno $(\mathrm{mM})$ representando las condiciones durante El Niño (mayo 1997 mayo 1998) y post-El Niño (mayo 1998-marzo 2000) en el interior de la Bahía de Concepción y plataforma media. Cada gráfico de contorno representa la temperatura y concentración de oxígeno para la estación 4 (A y B) y 18 (C y D), respectivamente.

\section{Pore water concentrations}

The vertical distribution of solutes in pore water is shown in Fig. 3 (November 1997) and Fig. 4 (March 1998). They represent the mean value estimated from two cores obtained simultaneously (mean $\pm \mathrm{SD}$ ). The pore water
$\mathrm{NH}_{4}{ }^{+}$concentrations show the typical vertical gradient, increasing in depth in both sampling periods and stations. The $\mathrm{NO}_{3}{ }^{-}$and $\mathrm{NO}_{2}{ }^{-}$ concentrations decreased in depth from the sediment-water interface or with the presence of subsurface maxima at $2-3 \mathrm{~cm}$ depth. The $\mathrm{NO}_{3}{ }^{-}$concentration profiles in the bay 
TABLE 1

Some relevant parameters describing the environmental conditions in the sediments of Concepción Bay and adjacent shelf during the sampling period

Algunos parámetros relevantes que describen las condiciones ambientales en los sedimentos de la Bahía Concepción y plataforma adyacente durante el período de muestreo

\begin{tabular}{|c|c|c|c|c|c|c|c|c|c|}
\hline & $\begin{array}{l}\mathrm{Eh} \\
(\mathrm{mV})\end{array}$ & $\begin{array}{l}\text { Oxygen layerb } \\
(\mathrm{cm})\end{array}$ & $\mathrm{pH}$ & $\begin{array}{l}\mathrm{DO} \\
(\mu \mathrm{M})\end{array}$ & Porosity & $\begin{array}{l}\mathrm{NO}_{3}^{-\mathrm{c}} \\
(\mu \mathrm{M})\end{array}$ & $\begin{array}{l}\text { Chl- } a^{\mathrm{d}} \\
\left(\mu \mathrm{g} \mathrm{g}^{-1}\right)\end{array}$ & $\underset{\left(\mathrm{mmol} \mathrm{m}^{-2}\right)}{\sum \mathrm{H}_{2} \mathrm{~S}^{\mathrm{d}}}$ & $\begin{array}{c}\text { Bacterial mats } \\
\text { Beggiatoa }\end{array}$ \\
\hline \multicolumn{10}{|l|}{ Bay sediments (Station 4) } \\
\hline \multicolumn{10}{|l|}{ November 1997} \\
\hline Bottom water & & & 7.54 & 98.1 & & 9.7 & & & \\
\hline Sediment: $1 \mathrm{~cm}$ & -20 & & 7.41 & & 0.91 & & 42.0 & 23.2 & absent \\
\hline Sediment: 3 to $20 \mathrm{~cm}$ & -124 to -184 & 0.5 & 7.36 & & 0.91 & & & & \\
\hline \multicolumn{10}{|l|}{ March 1998} \\
\hline Bottom water & & & 7.43 & 16.9 & & 13.9 & & & \\
\hline Sediment: $1 \mathrm{~cm}$ & +41 & & 7.44 & & 0.91 & & 195.5 & 15.1 & $2.42 \pm 2.88$ \\
\hline Sediment: 3 to $20 \mathrm{~cm}$ & -99 to -208 & 3 & 7.35 & & 0.86 & & & & \\
\hline \multicolumn{10}{|l|}{ Shelf sediments (Station 18) } \\
\hline \multicolumn{10}{|l|}{ November 1997} \\
\hline Bottom water & & & 7.52 & 25.4 & & $20.5-23.4$ & & & \\
\hline Sediment: $1 \mathrm{~cm}$ & +126 & & 7.35 & & 0.87 & & 22.6 & 1.0 & $4.65 \pm 1.75$ \\
\hline Sediment: 3 to $20 \mathrm{~cm}$ & $-19^{a}$ to -116 & 3 & 7.55 & & 0.79 & & & & \\
\hline \multicolumn{10}{|l|}{ March 1998} \\
\hline Bottom water & & & 7.49 & 16.6 & & 18.7-1.2 & & & \\
\hline Sediment: $1 \mathrm{~cm}$ & +195 & & 7.45 & & 0.89 & & 22.8 & 2.7 & $4.96 \pm 1.68$ \\
\hline Sediment: 3 to $20 \mathrm{~cm}$ & $+65^{\mathrm{a}}$ to -140 & 9 & 7.49 & & 0.81 & & & & \\
\hline
\end{tabular}

a. They are about $-100 \mathrm{mV}$ at 7 and $15 \mathrm{~cm}$ depth, respectively

b. Oxidized layer $(\mathrm{Eh}>0)$

c. Sellanes et al. (unpublished data). The values at shelf correspond to measurements at 30 and $87 \mathrm{~m}$ water depth

d. Gutiérrez (2000), Chl-a content at $0-1 \mathrm{~cm}, \mathrm{H}_{2} \mathrm{~S}$ inventory at $0-15 \mathrm{~cm}$ depth

e. Gallardo et al. (unpublished data). Total mass of bacteria expressed in $\mathrm{g} \mathrm{m}^{-2}$ present at $0-15 \mathrm{~cm}$, mean \pm SD from 3 cores

sediments (Station 4) in November showed a different pattern; concentrations increased in depth but with a notorious decrease between 4 and $8 \mathrm{~cm}$. From this depth to the bottom of the core, concentrations increased again and reached a maximum value of $7 \mathrm{mM}$. The $\mathrm{NO}_{3}{ }^{-}$ concentrations at surface sediments of the bay $(5 \mathrm{mM})$ were lower than in the shelf $(20 \mathrm{mM})$. However the $\mathrm{NH}_{4}{ }^{+}$surface concentrations varied between 59 and $60 \mathrm{mM}$ in both areas. In March, $\mathrm{NH}_{4}{ }^{+}$surface concentration was higher at the bay (Station 4) $(\sim 120 \mathrm{mM})$ with $\mathrm{NO}_{3}{ }^{-}$ concentration also showing a conspicuous increment at the same time in this station $(\sim 89$ $\mathrm{mM}) . \mathrm{NO}_{2}^{-}$concentrations were similar in both periods but being lower at the bay (Station 4).

\section{Diffusive fluxes}

The estimated diffusive fluxes of nitrogen compounds are shown in Table 2. These values correspond to the mean values $\pm \mathrm{SD}$, determined from two cores obtained simultaneously. The pore water pool of $\mathrm{NH}_{4}{ }^{+}$at the bay was higher than at the shelf, in contrast the $\mathrm{NO}_{2}^{-}$pool was higher at the shelf, both not showing differences between sampling periods. Differences in $\mathrm{NO}_{3}$ - pool were observed only at the bay, with highest values occurring during March (Table 2).

In general, the relatively higher values for $\mathrm{NH}_{4}{ }^{+}$diffusive fluxes suggest that this compound dominates the exchange of nitrogen between the sediment and the water column. However, the $\mathrm{NO}_{3}{ }^{-}$flux on the shelf (Station 18) during March 1998 is in the same order of magnitude as the $\mathrm{NH}_{4}{ }^{+}$flux, indicating that the production of $\mathrm{NO}_{3}{ }^{-}$in the sediments acquires relevance. Also, the negative fluxes of $\mathrm{NO}_{3}{ }^{-}$at the bay and shelf during March and November respectively, were associated with the lowest $\mathrm{NH}_{4}{ }^{+}$diffusive fluxes coincident with the 

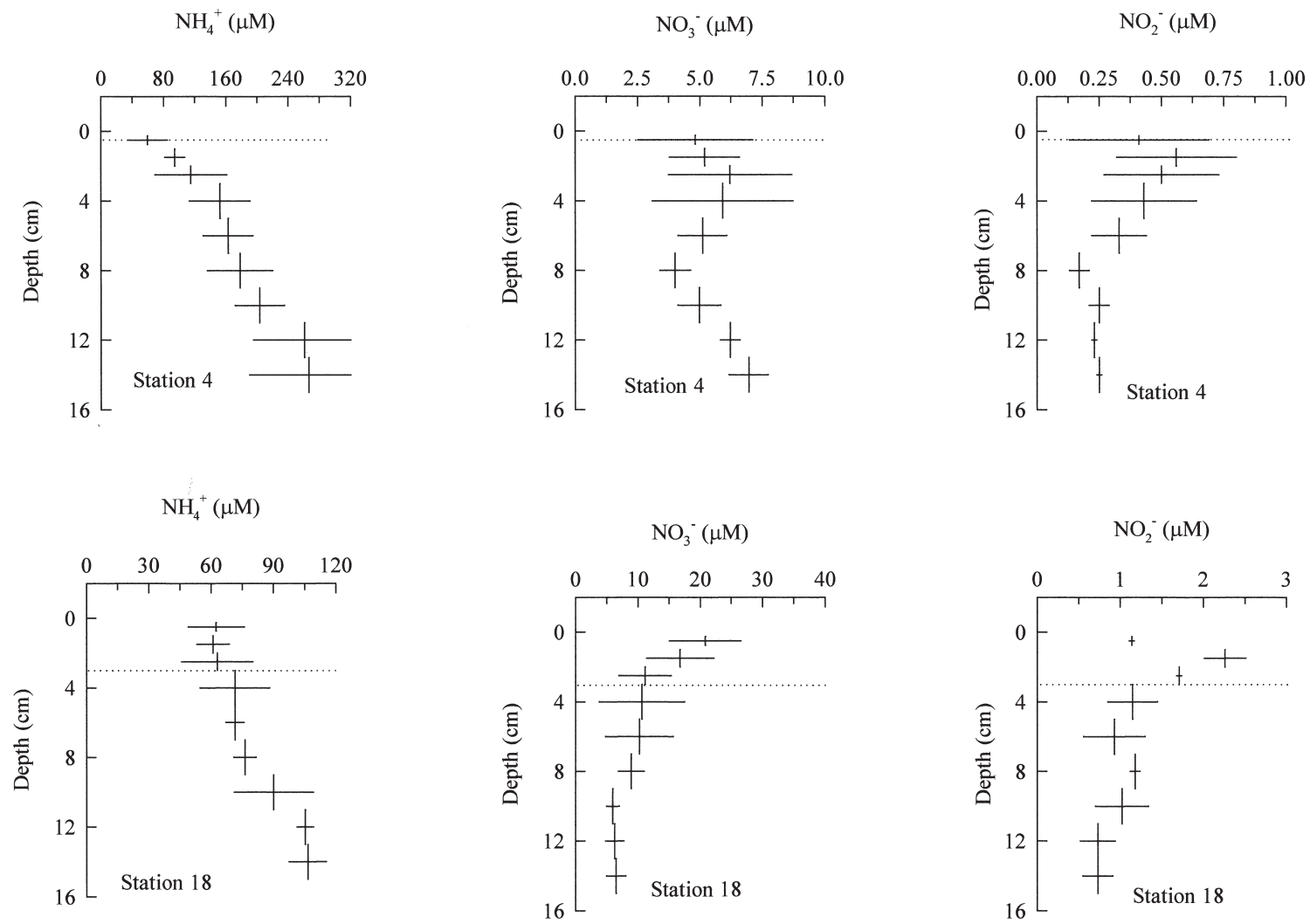

Fig. 3: Concentration of nitrogen compounds in pore waters in November 1997. Doted line shows the extent of oxidized layer. Error bars (horizontal) are the standard deviation of analyses from two replicates and vertical lines indicate section thickness.

Concentración de compuestos nitrogenados en el agua intersticial en noviembre de 1997. La línea punteada señala la extensión de la capa oxidada. Las barras de error son la desviación estándar del análisis de dos replicas y la línea vertical el espesor de la sección.

stronger gradient of Eh in the first centimetres of sediments, which is more evident in the bay sediments $(+41$ to $-99 \mathrm{mV})($ Table 1$)$.

\section{Benthic ammonium fluxes}

The time course curves are shown in Fig. 5. They were corrected for the initial ammonium concentration values (time zero) in the experiments. These initial values were $\sim 27$ and $16 \mathrm{mM}$ in November and in March they were 12 and $16 \mathrm{mM}$, in the bay and shelf sediment experiments, respectively. The concentration showed high variability during the first hour, therefore a good fit was not achieved for some curves (variance between 56 and $91 \%$ ) (Table $3)$. The slope of the curves suggests that the fluxes increased in time, with seasonal differences in the bay sediments, but not in the shelf. The $\mathrm{NH}_{4}{ }^{+}$fluxes in the shelf station (Station 18) during both periods were not significantly different from fluxes estimated in the bay (Station 4) during March (ANOVA, F $3,4=1.95, \mathrm{P}<0.1)$, probably due to the fact that bottom water showed low variability in oxygen content (Table 1). In contrast, the flux of the bay sediments in November was the lowest and significantly different $\left(0.55 \pm 0.11 \mathrm{mmol} \mathrm{m}^{-2}\right.$ day $^{-1}$, Tukey HSD test, $\left.\mathrm{P}<0.1\right)$ concurrent with a maximum concentration of bottom-water dissolved oxygen (Table 1).

\section{DISCUSSION}

A deepening of the oxidized layer was observed in both sites, consistent with the fact that anoxic conditions (in contrast with what happens during normal years; Ahumada \& Chuecas 1979) did not develop by the end of summer (Table 1). Besides, more aeration by benthic faunal activity was produced (Gutiérrez et al. 2000), which 

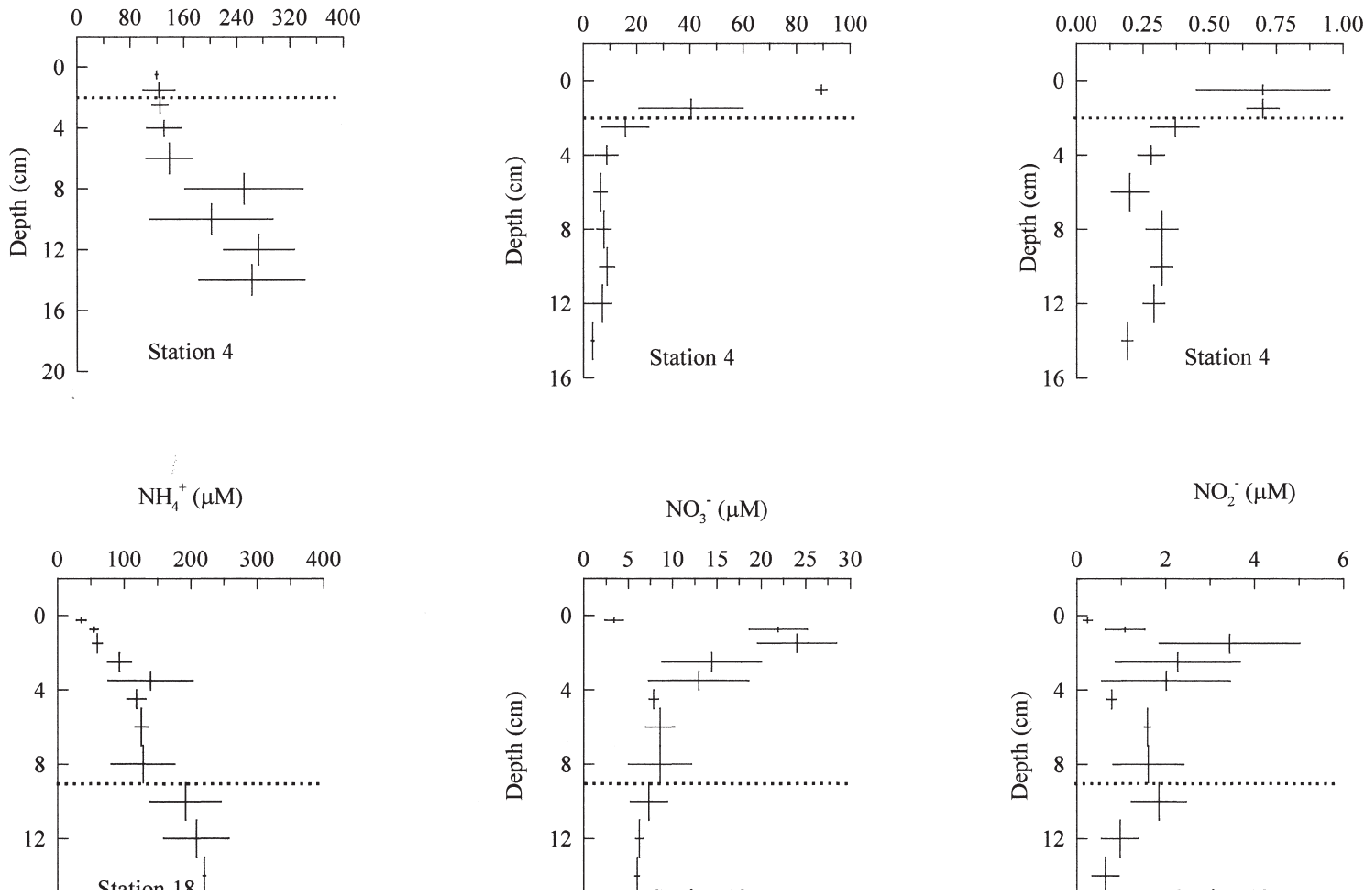

Fig. 4: Concentration of nitrogen compounds in pore waters in March 1998. Doted line shows the extent of oxidized layer. Error bars (horizontal) are the standard deviation of analyses from two replicates and vertical lines indicate section thickness.

Concentración de compuestos nitrogenados en el agua intersticial en marzo de 1998. La línea punteada señala la extensión de la capa oxidada. Las barras de error son la desviación estándar del análisis de dos replicas y la línea vertical el espesor de la sección.

TABLE 2

Diffusive fluxes and size of nitrogen compounds in pore waters estimated on sediments of Concepción Bay and adjacent shelf. Values are means \pm SD from two cores

Flujos difusivos e inventarios de compuestos nitrogenados estimados en los sedimentos de la Bahía Concepción y plataforma adyacente. Los valores corresponden a medias $\pm \mathrm{DE}$

\begin{tabular}{|c|c|c|c|c|}
\hline \multirow[t]{2}{*}{ Date } & \multicolumn{2}{|c|}{ Diffusive fluxes } & \multicolumn{2}{|c|}{ Pore water pool size ${ }^{a}$} \\
\hline & $\begin{array}{l}\text { Bay (Station 4) } \\
\left(\mathrm{mmol} \mathrm{m}^{-2} \mathrm{~d}^{-1}\right)\end{array}$ & $\begin{array}{l}\text { Shelf (Station 18) } \\
\quad\left(\mathrm{mmol} \mathrm{m}^{-2} \mathrm{~d}^{-1}\right)\end{array}$ & $\begin{array}{l}\text { Bay (Station 4) } \\
\left(\mathrm{mmol} \mathrm{m}^{-2}\right)\end{array}$ & $\begin{array}{l}\text { Shelf (Station 18) } \\
\quad\left(\mathrm{mmol} \mathrm{m}^{-2}\right)\end{array}$ \\
\hline \multicolumn{5}{|c|}{ November 1997} \\
\hline $\mathrm{NH}_{4}^{+}$ & $18.3 \pm 0.05 \times 10^{-2}$ & $5.9 \pm 0.01 \times 10^{-2}$ & $13 \pm 3$ & $6 \pm 1$ \\
\hline $\mathrm{NO}_{3}^{-}$ & $1.2 \pm 0.7 \times 10^{-2}$ & $-2.7 \pm 0.9 \times 10^{-2}$ & $0.4 \pm 0.1$ & $0.8 \pm 0.3$ \\
\hline $\mathrm{NO}_{2}^{-}$ & $4.5 \pm 1.3 \times 10^{-4}$ & $29 \pm 6.3 \times 10^{-4}$ & $0.03 \pm 0.01$ & $0.09 \pm 0.01$ \\
\hline \multicolumn{5}{|c|}{ March 1998} \\
\hline $\mathrm{NH}_{4}^{+}$ & $4.1 \pm 0.04 \times 10^{-2}$ & $23.7 \pm 0.18 \times 10^{-2}$ & $14 \pm 3$ & $8 \pm 2$ \\
\hline $\mathrm{NO}_{3}^{-}$ & $-17 \pm 0.4 \times 10^{-2}$ & $11 \pm 1.5 \times 10^{-2}$ & $1.7 \pm 0.4$ & $0.9 \pm 0.2$ \\
\hline $\mathrm{NO}_{2}^{-}$ & $-4.2 \pm 1.7 \times 10^{-4}$ & $8.9 \pm 4.4 \times 10^{-3}$ & $0.03 \pm 0.01$ & $0.13 \pm 0.06$ \\
\hline
\end{tabular}

Values \pm SD from two cores

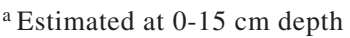



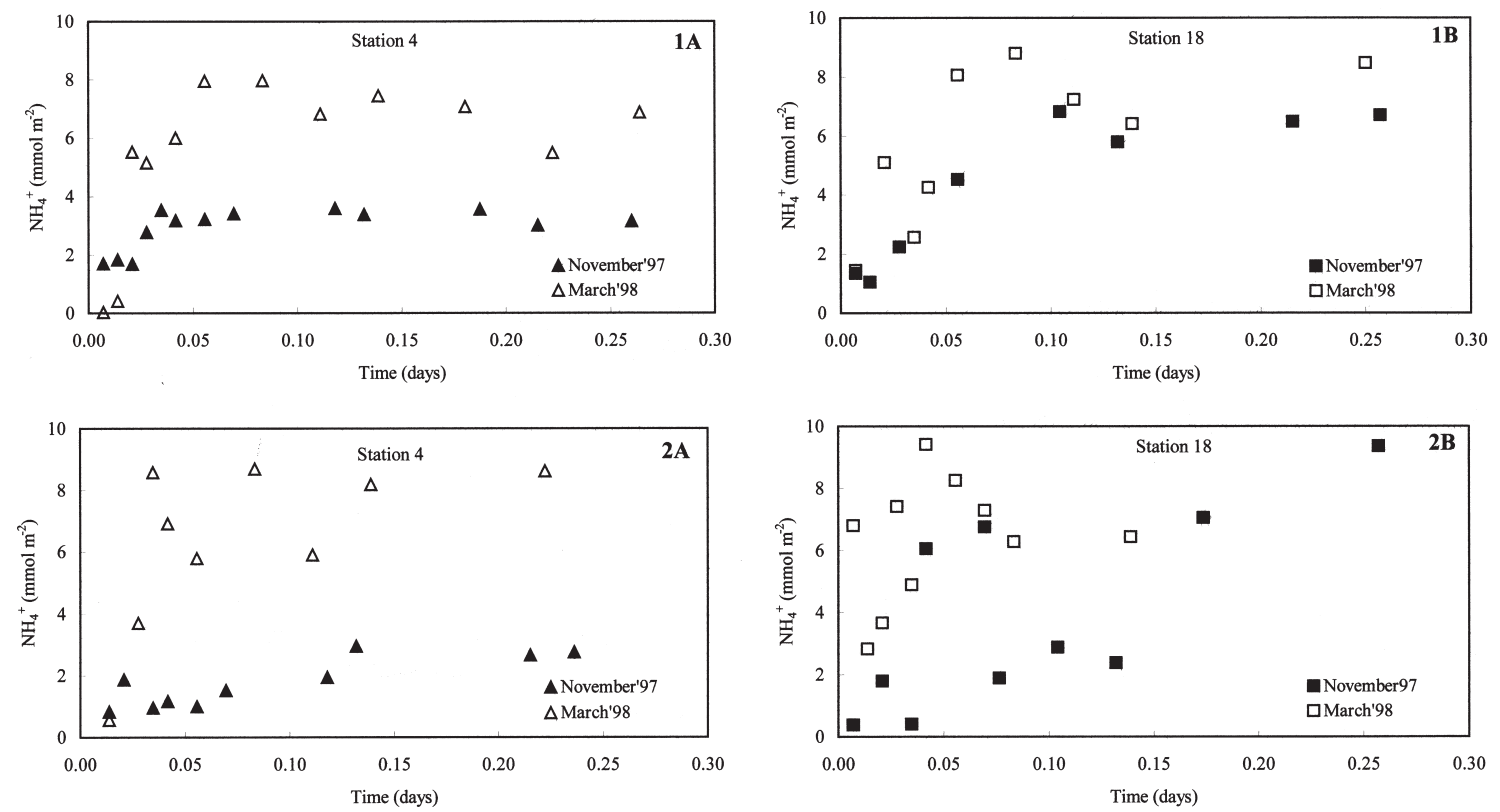

Fig. 5: Ammonium flux from incubation cores 1 and 2 in Station 4 (1A and 2A) and 18 (1B and 2B) in both sampling periods.

Flujos de amonio determinados en los testigos de incubación 1 y 2 en la estación 4 (1A and 2A) y 18 (1B and 2B) en ambos períodos de muestreo.

could have affected the pore-water chemistry of the bay sediments. In fact, the $\mathrm{NH}_{4}^{+}$ concentrations in the bay $(\sim 50-90 \mathrm{mM}$, surface sediments) are lower than in previous reports ( 200-600 mM; Farías \& Salamanca 1990, Farías et al. 1995), in consequence lower pore water pool of $\mathrm{NH}_{4}^{+}$are observed than those reported during no El Niño conditions (between 20 to $142 \mathrm{mmol} \mathrm{m}^{-2}$, Graco et al. 2001) (Table $2)$. Nitrification should be favored in oxic conditions. $\mathrm{NO}_{2}-$ profiles showed relatively low concentrations with maximum values around 2 $\mathrm{cm}$ deep and just above the depth where $\mathrm{NO}_{3}$ reaches the maximum. This constitutes the typical profile that shows $\mathrm{NO}_{2}^{-}$as an intermediate product in the nitrification process (Atlas \& Bartha 1998). However, the influence of dissolved oxygen in these processes is not clear. The $\mathrm{NO}_{3}^{-}$pore water pools were higher in March at the bay sediments, where the highest $\mathrm{NO}_{3}{ }^{-}$concentrations and a deeper oxidized layer were observed but not coincident with the maximum DO at the bottom waters. This indicates a response time since water column changed environmental conditions appear and the effect in the sediments develop. The bay sediments seem to be more affected than the shelf sediments due to they are normally under highly reducing conditions $(\mathrm{Eh}<-100 \mathrm{mV})$.
Positive correlations between nitrogen species $\left(\mathrm{NO}_{3}^{-}\right.$and $\left.\mathrm{NH}_{4}^{+}\right)$and bottom-water oxygen have been reported in shallow waters (Cowan et al. 1996, Graco et al. 2001), reflecting the sensitivity of nitrification and denitrification processes relative to $\mathrm{DO}$ concentrations. It is possible that $\mathrm{NO}_{3}{ }^{-}$ formation could occur more favourably in superficial regions of the sediments where the overlying water is more oxygenated supplying oxidant $\left(\mathrm{O}_{2}\right.$ or $\mathrm{Mn}$, Hulth et al. 1999). Therefore the occurrence of increased bottomwater oxygen ( $>45.4 \mathrm{mM}$ ) could promote nitrification in the upper sediment layers, especially at the bay sediment.

\section{Diffusive fluxes}

The $\mathrm{NO}_{3}{ }^{-}$negative fluxes and related lower $\mathrm{NH}_{4}{ }^{+}$fluxes in the bay and shelf during March and November, respectively (Table 2), could be indicating a response to a nitrification and a rapid denitrification process (Hulth et al. 1999), favored by sulphide inventories in the sediments lower than in normal periods (Table 1; 192.4 mmol m${ }^{-2}$ during non-El Niño, Gutiérrez 2000), since the high sulphide concentrations inhibit both processes (nitrification-denitrification, Joye \& Hollibaugh 1995). Also, the relatively lower 
$\mathrm{NO}_{3}{ }^{-}$fluxes could have been due to denitrification as a dominating $\mathrm{NO}_{3}{ }^{-}$-consuming process in the sediment (Jensen et al. 1990, Hulth et al. 1999, Usui et al. 2001). However, though the $\mathrm{N}_{2} \mathrm{O}$ produced in this process would have been an important clue to clarify this point, it was not measured in this study. At the shelf the negative flux could also result from an uptake of the overlying water combined with $\mathrm{NO}_{3}{ }^{-}$production from within the sediments with a positive redox potential (Jenkins \& Kemp 1984); actually the $\mathrm{NO}_{3}{ }^{-}$concentration in the superficial sediments is similar to values found in the shelf bottom water (Gutiérrez 2000) (Table 1).

The differences in $\mathrm{NO}_{3}{ }^{-}$and $\mathrm{NH}_{4}{ }^{+}$fluxes between stations and sampling periods could be related also with the organic matter availability. In March 1998 a weak reactivation of upwelling was observed (Gutiérrez 2000) probably due to the development of an algae bloom. Actually, higher Chl-a concentrations in superficial sediments of the bay (Station 4) were observed compared to the previous period (November 1997, Gutiérrez 2000) (Table 1). Probably the shallowness of the bay could decrease the oxygen penetration reducing nitrification as observed after a bloom in shallow anoxic sediments (Jenkins \& Kemp 1984, Jensen et al. 1990). On the shelf sediments, the mineralization of sedimented organic matter is conducted in a permanent more oxygenated environment. Thus, the organic material availability associated with the redox potential, which determines the oxidative pathways of organic matter mineralization (Atlas \& Bartha 1998, Usui et al. 2001), is an important factor controlling the nitrogen species abundance in both areas. Besides, the differences in the diffusive fluxes are responding to the differences observed in the environmental conditions in both sampling areas (bay and shelf) emphasized by the shallowness of the bay (Table 1 and 2).

Temporal differences in the bay (Station 4) attributable to the activity of the benthic bacterium Beggiatoa sp. mats are discarded. During sampling period, and also in response to El Niño-changed conditions, lower bacterial biomasses were observed. Reported values for the summer season range from $29-35 \mathrm{~g} \mathrm{~m}^{-2}$ for Beggiatoa sp. to $\sim 202-774 \mathrm{~g} \mathrm{~m}^{-2}$ for Thioploca sp. (Fossing et al. 1995, Graco et al. 2001). These bacteria can accumulate high intracellular concentrations of $\mathrm{NO}_{3}{ }^{-}$(300-500 $\mathrm{mM}$ ) and elemental sulfur (Fossing et al. 1995, Jørgensen \& Gallardo 1999), being responsible for the $\mathrm{NO}_{3}^{-}$fluxes into the sediments (consumption) (Graco et al. 2001). In this study, the highest negative $\mathrm{NO}_{3}$ diffusive fluxes were estimated in March 1998 $\left(-17 \times 10^{-2} \mathrm{mmol} \mathrm{m}^{-2} \mathrm{day}^{-1}\right)$ while a positive flux was found during November 1997. Beggiatoa sp. was present only in March 1998 (absent during November 1997) (Table 1) suggesting an uptake of $\mathrm{NO}_{3}{ }^{-}$related with the activity of this bacterium. However, at the shelf, the $\mathrm{NO}_{3}$ - diffusive fluxes where negative (uptake) in November and positive in March (2.7 and $11 \times 10^{-2} \mathrm{mmol} \mathrm{m}^{-2} \mathrm{day}^{-1}$, respectively) besides Thioploca sp. was present in both sampling periods, though in low biomasses (Table 1). Thus, its effect over the fluxes could not be observed clearly.

The diffusive fluxes estimated through solute concentration gradients do not consider the bioturbation effects (advective flux). Though this results in lower values than the total fluxes measured through sediment core incubations, the diffusive fluxes provide a general picture of the biogeochemical processes occurring in the sediments.

\section{Benthic ammonium flux at the sediment-water interface}

Previous reports on ammonium fluxes within the bay indicated higher values, between 5 and $9 \mathrm{mmol} \mathrm{m}^{-2}$ day $^{-1}$ (Farías et al. 1996, Thamdrup \& Canfield 1996), when the normal "anoxic" conditions were present. During the sampling period a lower amount of organic matter was settled with oxic conditions prevailing, evidenced this by lower Chl-a concentrations in surface sediments (Table 1) compared to those reported for other periods $(\sim 165$ and $1,120 \mathrm{mg}$ $\mathrm{g}^{-1}$ in November 1998 and March 1999, respectively, Gutiérrez 2000, Graco et al. 2001). This produces changes in the biogeochemical processes in the sediments affecting mainly the $\mathrm{NH}_{4}{ }^{+}$concentrations since these are highly sensitive to changes of organic matter in the sediments (Blackburn \& Henriksen 1983, Jensen et al. 1990).

Although the ammonium fluxes from sediment incubation experiments were low, they indicate that the sediment continue representing a source of ammonium to the overlying water during El Niño. The relative increase in the flux of other nitrogen species in comparison to "normal" periods is not discarded. If we consider that the water column production is $\sim 2-9 \mathrm{~g} \mathrm{C} \mathrm{m}^{-2}$ day $^{-1}$ over the shelf, and $\sim 3.5 \mathrm{~g} \mathrm{C} \mathrm{m}^{-2}$ day $^{-1}$ in the bay in normal years (annual basis) (Pantoja et al. 1987, Fossing et al. 1995, Dellarosa 1998), and 
assuming (1) 25-40\% loss in the sediments (Bernal et al. 1989, Farías 1998) and (2) 80$90 \%$ of $\mathrm{N}$ is regenerated from Concepción Bay sediments during the spring-summer period (Farías et al. 1995), then a nitrogen flux between 4 to $32 \mathrm{mmol} \mathrm{N} \mathrm{m}{ }^{-2}$ day $^{-1}$ would have been expected in both areas (assuming a C:N ratio equivalent to Redfield). In March 1998, primary production of about $0.17-0.18 \mathrm{~g} \mathrm{C} \mathrm{m}^{-2}$ day $^{-1}$ was determined in the shelf area (Ulloa personal communication). Using the same criteria described above, the nitrogen flux should have been $0.4-0.7 \mathrm{mmol} \mathrm{N} \mathrm{m}^{-2}$ day $^{-1}$, in the lower range to that estimated from the ammonium incubation experiments (Table 3). However this approximation does not reflect the processes occurring within the sediments. The mineralization of organic material could have been stimulated during the study period. Normally, these sediments show relatively high $\mathrm{C}: \mathrm{N}$ ratios compared to those found between 1997 and the first half of 1998 (Gutiérrez et al. 2000, Neira et al. 2001), suggesting the presence of lower amounts of refractory organic carbon in the sediments during this study. This implies that when anomalous oxygenation occurs, a mineralization of previously deposited organic mater is developed. The nitrogen flux directions as $\mathrm{NO}_{3}$ could change or increase, representing an influx during normal periods in the area (Graco et al. 2001). Direct measurements of benthic $\mathrm{NO}_{3}{ }^{-}$ fluxes were not performed in this study, but they could have represented a flux from the sediments, as suggested by the estimated diffusive fluxes.

Thus, during the study period the nutrient fluxes did not reflect only the degradation of recent settled organic material. Ventilation and feeding activity stimulate the microbial processes increasing the nutrient release from sediments (Kristensen et al. 1991, Christensen et al. 2000). In the bay (Station 4, lowest flux), significantly higher mixing rates were observed in November 1997 in agreement with higher bioturbation potential observed. In the shelf (Station 18) instead, the same bioturbating species dominated during the whole sampling period (Gutiérrez et al. 2000) with a bioturbation potential lower than in the bay. Thus, the fluxes found in this study are also a result from this variability, which in turn is related to the oxygen content and to the organic matter availability. The denitrification is another important process that could be increased during high bioturbation activity (Kristensen et al. 1991) in the bay, which supplies oxidants to the underlying anoxic

TABLE 3

Ammonium fluxes from incubation cores in the study area. Values are means \pm SE of curve fit

Flujos de amonio estimados por incubación de sedimento en el área de estudio.

Los valores corresponden a medias $\pm \mathrm{EE}$ de la curva ajustada

Total flux (mmol m $\left.\mathrm{m}^{-2} \mathrm{day}^{-1}\right)$

Variance $(\%)$

\begin{tabular}{ccc}
\hline & Total flux $\left(\mathrm{mmol} \mathrm{m} \mathrm{day}^{-1}\right)$ & Variance $(\%)$ \\
\hline November 1997 & & \\
Bay sediments (Station 4) & $0.47 \pm 0.12$ & 56 \\
Core 1 & $0.63 \pm 0.14$ & 67 \\
Core 2 & $0.55 \pm 0.11$ & \\
Mean & & 51 \\
Shelf sediments (Station 18) & $1.79 \pm 0.25$ & 59 \\
Core 1 & $1.89 \pm 0.59$ & \\
Core 2 & $1.84 \pm 0.07$ & \\
Mean & & \\
March 1998 & & \\
Bay sediments (Station 4) & $1.75 \pm 0.45$ & \\
Core 1 & $2.60 \pm 0.60$ & \\
Mean & $2.18 \pm 0.60$ & \\
Core 1 & & \\
Core 2 & $1.57 \pm 0.67$ & 51 \\
Mean & $2.70 \pm 0.95$ & \\
Shelf sediments (Station 18) & $2.14 \pm 0.80$ & \\
\hline
\end{tabular}

Values \pm standard error of curve fit mean $\pm \mathrm{SD}$ 
regions. This process was probably higher during El Niño, but it could not be estimated in this study.

\section{Approach of the 1997-1998 El Niño effects on the total fluxes}

The incubation chamber fluxes represent a reasonable approach to the total flux from the sediments (Table 3 ). They result from several processes acting at the same time and in two levels, i.e., molecular and advective. The molecular flux is proportional to the vertical gradient of dissolved solute concentrations described by the first Fick's law (Li 1974, Berner 1980, Boudreau 1997), depending on the diffusion coefficient $\left(D_{S}\right)$. The advective flux depends on the gradient determined by particle reworking and fluid motion due to bioturbation, quantified through a biodiffusive coefficient $\left(D_{B}\right)$ and irrigation coefficient $\left(D_{I}\right)$.

Thus, the total flux $\left(\mathrm{J}_{\mathrm{t}}\right)$ is given by:

$$
\mathrm{J}_{\mathrm{t}}=\phi\left(\mathrm{D}_{\mathrm{S}}+\mathrm{D}_{\mathrm{B}}+\mathrm{D}_{\mathrm{I}}\right) \partial \mathrm{C} / \partial \mathrm{z}
$$

Where, $\phi$ is porosity and $\partial \mathrm{C} / \partial \mathrm{z}$ is the concentration gradient. The irrigation flux can be estimated by difference using the above relation. $\mathrm{D}_{\mathrm{B}}$ coefficients estimated for the same sampling period are between $1.1-5.6 \times 10^{-6} \mathrm{~cm}^{2}$ $\mathrm{s}^{-1}$ in bay sediments and $1.5 \times 10^{-6} \mathrm{~cm}^{2} \mathrm{~s}^{-1}$ in the shelf (Gutiérrez 2000). Thus, the calculated $\mathrm{NH}_{4}{ }^{+}$advective flux due to irrigation varied between 0.31 and $2.13 \mathrm{mmol} \mathrm{m}^{-2}$ day $^{-1}$ in bay sediments and between 1.78 and $1.90 \mathrm{mmol} \mathrm{m}^{-2}$ day $^{-1}$ in shelf sediments. This compared to the total fluxes measured (Table 3), suggests that the irrigation is the main process regulating the exchange of $\mathrm{NH}_{4}{ }^{+}$in the sediment-water interface. Similar results were found in the bay during non-El Niño conditions (Farías et al. 1995). However, the irrigation coefficients $\left(D_{I}\right)$ estimated in this study, $\sim 0.2-3 \times 10^{-4} \mathrm{~cm}^{-2} \mathrm{~s}^{-1}$ in the bay sediments and $1-9 \times 10^{-4} \mathrm{~cm}^{-2} \mathrm{~s}^{-1}$ in the shelf sediments, are one order of magnitude higher than those estimated previously in the bay (1.5-3.4 x $10^{-5} \mathrm{~cm}^{2} \mathrm{~s}^{-1}$; Farías et al. 1995), suggesting that the fluxes are more influenced by the benthic animal activities in this period.

These results are in agreement with those found by others, where an increased bioturbating activity and an enhanced vertical penetration of infauna during El Niño is determined, specially in shallow zones of the bay and at the greatest depth over the shelf (Gutiérrez et al. 2000, Neira et al. 2001). This change was associated with oxygen levels higher than in normal years and with reduced fluxes of bulk and reactive organic carbon to the sediments. Thus, the increase of the organic matter remineralization is facilitated by the oxygenation of the sediments through the activities of benthic animals. Also, in the sediments under anoxia for large periods, the exposition to oxygen by resuspension, diffusion or bioturbation, promotes mainly the oxidation of refractory material, enhancing the extent of organic carbon degradation (Hulthe et al. 1998).

The results of this study suggest that the lower exchange of $\mathrm{NH}_{4}{ }^{+}$in the sediment-water interface, relative to previous reports, is associated to the anomalous higher DO content in the bottom water, consequence in turn of the 1997-1998 El Niño event. This could also support that nitrification process in the top centimeters of the sediment occurred, suggested by the high pore-water nitrate concentrations measured. A potential increase in other nitrogen compound fluxes in relation to the low $\mathrm{NH}_{4}{ }^{+}$fluxes, in spite of the lower primary productivity, is expected due to the enhanced organic matter mineralization within the sediments.

\section{ACKNOWLEDGMENTS}

The authors wish to thank Dr. V. A. Gallardo for sharing unpublished data, to Dr. K. Kremling for his critical reading of the first version of this manuscript and also special thanks to MSc.Verónica Molina for her valuable comments. We extend our gratitude to Mrs. M ${ }^{\text {a }}$ Raquel Lazo de la Vega for grammar corrections. Three anonymous referees contributed to greatly improve this manuscript. This study was supported by FONDAPHumboldt program (CONICYT, Chile).

\section{LITERATURE CITED}

AHUMADA R \& L CHUECAS (1979) Algunas características hidrográficas de la Bahía Concepción (360 40 $\mathrm{S} ; 7^{\circ} 02^{\prime}$ W) y áreas adyacentes, Chile. Gayana Miscelánea (Chile) 8: 1-56.

AHUMADA R, A RUDOLPH \& V MARTÍNEZ (1983) Circulation and fertility of waters in Concepción Bay. Estuarine, Coastal and Shelf Science 16: 95-105.

AHUMADA R, R MORALES, A RUDOLPH \& A MATRAI (1984) Efectos del afloramiento costero en la diagénesis temprana de los sedimentos de la Bahía Concepción, Chile. Boletín de la Sociedad de Biología de Concepción (Chile) 55: 135-146.

AHUMADA R (1989) Producción y destino de la biomasa fitoplanctónica en un sistema de bahías en Chile Central: Una hipótesis. Biología Pesquera 18: 53-66.

ARCOS D F \& MA SALAMANCA (1984) Distribución de clorofila y condiciones oceanográficas superficiales 
frente a Chile central (Latitudes $32^{\circ} \mathrm{S}-38^{\circ} \mathrm{S}$, Febrero 1982). Biología Pesquera (Chile)13: 5-14.

ARCOS DF \& RC WILSON (1984) Upwelling and the distribution of chlorophyll- $a$ within the Bay of Concepción, Chile. Estuarine, and Coastal Shelf Science 18: 25-35.

ATLAS R \& R BARTHA (1998) Biogeochemical cycling: nitrogen, sulfur, phosphorus, iron and other elements. In: Atlas R \& R Bartha (eds) Microbial ecology, fundamentals and applications: 414-459. Addison Wesley Longman Inc., San Francisco, California, USA.

BERNAL P, R AHUMADA, H GONZÁLEZ, S PANTOJA \& V A TRONCOSO (1989) Flujo de carbono en un modelo trófico pelágico para Bahía de Concepción, Chile. Biología Pesquera 18: 5-14.

BERNER RA (1980) Early Diagenesis: a theorical approach. Princeton University Press, London, United Kingdom. iv + 421 pp

BLACKBURN TH \& K HENRIKSEN (1983) Nitrogen cycle in different types of sediments from Danish waters. Limnology and Oceanography 28: 477-493.

BOUDREAU B (1997) Diagenetic models and their implementation. Springer-Verlag, Berlin, Germany. viii + 414 pp

BRANDHORST W (1971) Condiciones oceanográficas estivales frente a la costa de Chile. Revista de Biología Marina, Departamento de Oceanografía, Universidad de Chile. Valparaíso, Chile 14: 34-84.

BUCHANAN JB (1984) Sediment analysis. In: Holme NA \& NA McIntyre (eds). Methods for the study of marine benthos. 41-65. Blackwell Scientific Publications, Oxford, United Kingdom.

CARRASCO FD (1986) Conjuntos faunísticos de anélidos y sus variaciones temporales en el macrobentos de la Bahía de Concepción, Chile. Tesis Magister. Universidad de Concepción, Concepción, Chile. viii + 79 pp.

CHRISTENSEN B, A VEDEL \& EKRISTENSEN (2000) Carbon and nitrogen fluxes in sediment inhabited by suspension-feeding (Nereis diversicolor) and non-suspension-feeding ( $N$. virens) polychaetes. Marine Ecology Progress Series 192: 203-217.

COWAN J, J PENNOCK \& R BOYNTON (1996) Seasonal and interanual patterns of sediment-water nutrient and oxygen fluxes in Mobile Bay, Alabama, USA: regulating factors and ecological significance. Marine Ecology Progress Series 41: 229-245.

DELLAROSA V (1998) Producción primaria anual en sistemas de alta producción biológica. Tesis Doctorado, Universidad de Concepción, Concepción, Chile. xix $+142 \mathrm{pp}$.

ENFIELD D (1989) El Niño, past and present. Reviews of Geophysics 27: 159-187.

FARÍAS L \& MA SALAMANCA (1990) Distribución vertical de sulfato, cloruro y amonio en el agua intersticial de sedimentos de bahía de Concepción, Chile. Ciencia y Tecnología del Mar 14: 33-44.

FARÍAS L, L CHUECAS \& MA SALAMANCA (1995) Flujos de amonio a través de la interfase agua-sedimento de Bahía Concepción (Chile centro-sur): mecanismos de intercambio químico. Gayana Oceanológica (Chile) 3: 99-118.

FARÍAS L, L CHUECAS \& MA SALAMANCA (1996) Effect of coastal upwelling on nitrogen regeneration from sediments and ammonium supply to the water column in Concepcion Bay, Chile. Estuarine, Coastal and Shelf Science 43:137-155.

FARÍAS L (1998) Destino del nitrógeno orgánico en sedimentos de una Bahía eutroficada: reciclaje versus acumulación. Tesis Doctoral, Universidad de Concepción, Concepción, Chile. xviii + 157 pp.
FERDELMAN T, C LEE, S PANTOJA, J HARDER, B BEBOUT \& H FOSSING (1997) Sulfate reduction and methanogenesis in a Thioploca-dominated sediments off the coast of Chile. Geochimica et Cosmochimica Acta 61: 3065-3079.

FOSSING H, VA GALLARDO, BB JØRGENSEN, M HÜTTEL, LP NIELSEN, H SCHULZ, DE CANFIELD, S FORSTER, RN GLUD, JK GUNDERSEN, J KÜVER, NB RAMSING, A TESKE, B THAMDRUP, O ULLOA (1995) Concentration and transport of nitrate by the matforming sulphur bacterium Thioploca. Nature 374: 713-715.

GALLARDO VA (1977) Large benthic microbial communities in the sulfide biota under Perú-Chile subsurface counter-current. Nature 268: 331-332.

GRACO M, L FARÍAS, V MOLINA, D GUTIÉRREZ \& LP NIELSEN (2001) Massive developments of microbial mats following phytoplankton blooms in a naturally eutrophic bay: implications for nitrogen cycling Limnology and Oceanography 46:821-832.

GRASSHOFF K, M EHRHARDT \& K KREMLING (1983) Methods of seawater analysis. Second edition. Verlag Chemic, Weinheim, Germany. xvii + 419 pp.

GUTIÉRREZ D, VA GALLARDO, S MAYOR, C NEIRA, C VÁSQUEZ, J SELLANES, M RIVAS, A SOTO, F CARRASCO \& M BALTAZAR (2000) Effects of dissolved oxygen and fresh organic matter on macrofaunal bioturbation potential in sublittoral bottoms off central Chile, during 1997-1998 El Niño. Marine Ecology Progress Series 202: 81-99.

GUTIÉRREZ D (2000) Bioperturbación y macrofauna en fondos sublitorales de un área de surgencias frente a Chile central $\left(36^{\circ} 30^{\prime} \mathrm{S}\right)$ : variación espacial y temporal en el periodo 1997-1999. Tesis Doctoral, Universidad de Concepción, Concepción, Chile. xiii + 221pp.

HULTH S, RC ALLER \& F GILBERT (1999) Coupled anoxic nitrification/manganese reduction in marine sediments. Geochimica et Cosmochimica Acta 63: 49-66.

HULTHE G, HULTH S \& POJ HALL (1998) Effect of oxygen on degradation rate of refractory and labile organic matter in continental margin sediments. Geochimica et Cosmochimica Acta 62: 1319-1328.

JENSEN M, E LOMSTEIN \& J SORENSEN (1990) Benthic $\mathrm{NH}_{4}^{+}$and $\mathrm{NO}_{3}{ }^{-}$flux following sedimentation of a spring phytoplankton bloom in Aarhus Bight, Denmark. Marine Ecology Progress Series 61:87-96.

JENKINS M \& M KEMP (1984) The coupling of nitrification and denitrification in two estuarine sediments. Limnology and Oceanography 29: 609-619.

JØRGENSEN BB \& VA GALLARDO (1999) Thioploca spp.: filamentous sulfur bacteria with nitrate vacuoles. FEMS Microbiology Ecology 28: $301-313$

JOYE S \& J HOLLIBAUGH (1995) Influence of sulphide inhibition of nitrification on nitrogen regeneration in sediments. Science 70: 623-625

KRISTENSEN E, MH JENSEN \& RC ALLER (1991) Direct measurement of dissolved inorganic nitrogen exchange and denitrification in individual polychaete (Nereis virens) burrows. Journal of Marine Research 49: 355-377.

LI Y (1974) Diffusion of ions in sea water and deep-sea sediments. Geochimica et Cosmochimica Acta 38: 703-714.

MCPHADEN MJ (1999) El Niño: the child prodigy of 1997-1998. Nature 398: 559-562.

NEIRA C, J SELLANES, A SOTO, D GUTIÉRREZ \& VA GALLARDO (2001) Meiofauna and sedimentary 
organic matter off central Chile: response to changes caused by the 1997-1998 E1 Niño. Oceanologica Acta 24: 313-328.

PANTOJA S, H GONZÁLEZ \& P BERNAL (1987) Sizefractioned photoautotrophic production in a shallow bay. Biología Pesquera (Chile) 16: 99-105.

PETERSON WT, D ARCOS, G MCMANUS, H DAM, D BELLANTONI, T JHONSON \& P TISELIUS (1988) The nearshore zone during coastal upwelling: daily variability between primary and secondary production off central Chile. Progress in Oceanography 20: 1-40.

ROA R, VA GALLARDO, B ERNST, M BALTAZAR, JI CAÑETE \& S HENRÍQUEZ-BRIONES (1995) Nursery ground, age structure and abundance of juvenile squat lobster Pleuroncodes monodon on the continental shelf off central Chile. Marine Ecology Progress Series 116: 47-54.

SALAMANCA MA (1988) ${ }^{210} \mathrm{~Pb}$ and trace metals distribution in Concepción Bay sediments, Chile. M.Sc. Thesis. Marine Science Research Center, SUNY, Stony Brook, New York, USA. vii +84 pp.

SCHULZ HN, BB JØRGENSEN, HA FOSSING \& NB RAMSING (1996) Community structure of filamentous, sheath-building sulfur bacteria,
Thioploca spp., off the coast of Chile. Applied and Environmental Microbiology 62: 1855-1862.

SCHOLL DW, MN CHRISTENSEN, R VON HUENE \& MS MARLOW (1970) Peru-Chile trench. sediments and sea-floor spreading. Geological Society of America Bulletin 81: 1339-1360.

SOBARZO M, D FIGUEROA \& D ARCOS (1997) The Influence of winds and tides in the formation of circulation layers in a Bay, a case study: Concepción Bay, Chile. Estuarine, Coastal and Shelf Science 45: 729-736.

THAMDRUP B \& D CANFIELD (1996) Pathways of carbon oxidation in continental margin sediments off central Chile. Limnology and Oceanography 41: $1629-1650$.

USUI T, I KOIKE \& N OGURA (2001) $\mathrm{N}_{2} \mathrm{O}$ production, nitrification and denitrification in an estuarine sediment. Estuarine, Coastal and shelf Science 52: 769-781.

WILLIAMS PJ \& NW JERKINSON (1982) A transportable microprocessor controlled precise Winkler titration suitable for field station and shipboard use. Limnology and Oceanography 27: 576-584.

ZAR JH (1974) Biostatistical analysis. Prentice Hall Inc., Englewood Cliffs, New Jersey, USA. 620 pp. 